\title{
METHODS FOR THE ASSESSMENT OF RURAL SOCIAL INFRASTRUCTURE NEEDS
}

\author{
Gintarè Vaznonienè, Rasa Pakeltiené $\dot{1}^{1}$
}

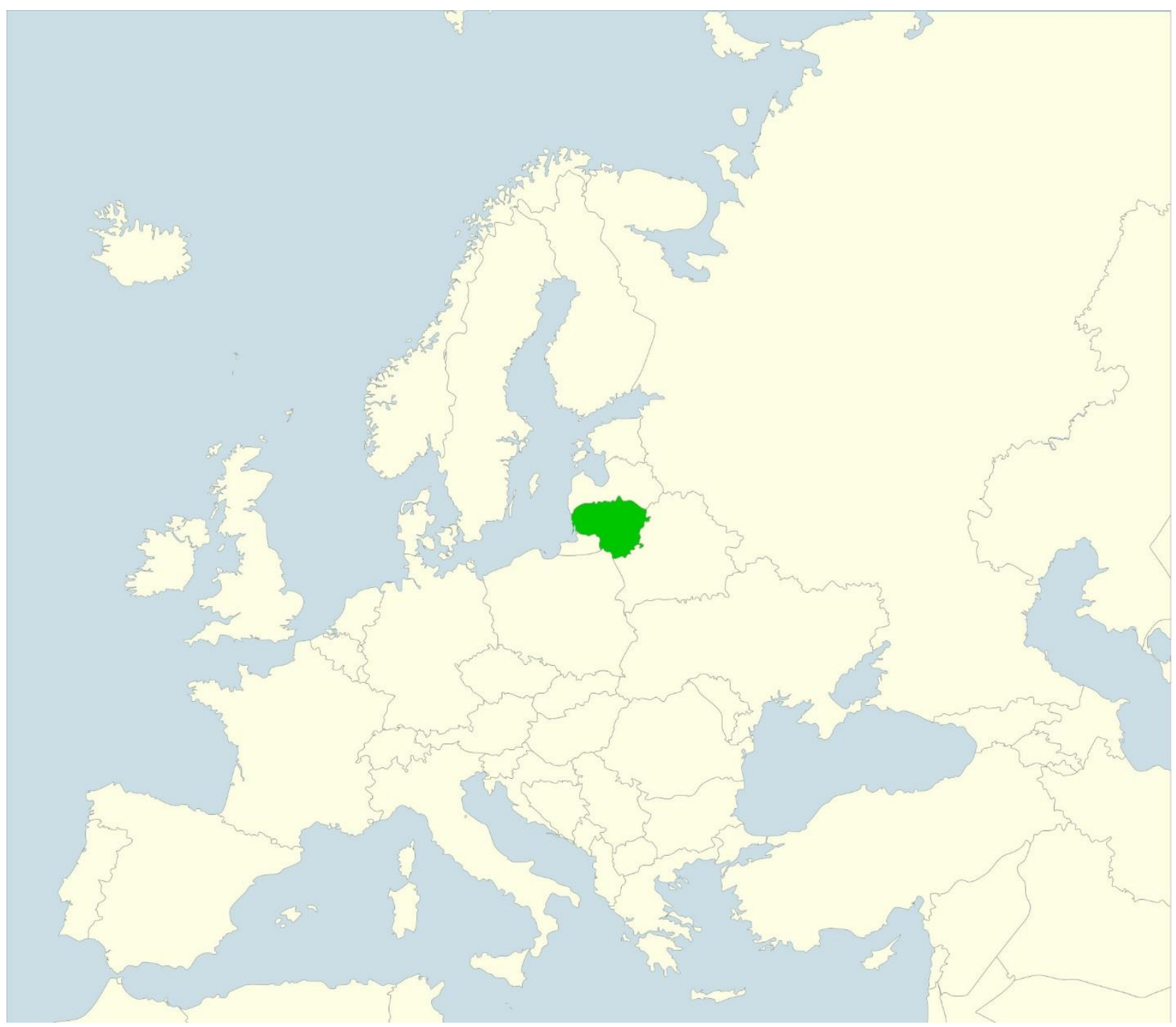

1 Assoc. prof. dr. Gintaré Vaznoniené, Lect dr. Rasa Pekeltiené, Business and Rural Development Management Institute, Faculty of Economics and Management, Aleksandras Stulginskis University, Studentu Str. 11, 53361 Kaunas, Lithuania, e-mails: gintarej@gmail.com, rasa.pakeltiene@asu.It 


\begin{abstract}
This article reveals the importance of different methods for assessment of social infrastructure (SI) development needs in rural areas. Rural social infrastructure is a significant element of rural territories interpreted in different ways: as social and economic system, basic services for local community, social bridge for integrating different social groups into the society, important factor for satisfaction of rural people's needs and acknowledgement of their human rights. Besides the mentioned importance of SI to rural areas and rural community, the lack of exploration of methods for analysis of the needs for developing rural social infrastructure has been noticed in the scientific literature. The research aim is therefore to analyse the methods for assessment of needs of rural social infrastructure. The research question has been set accordingly: how different methods for need analysis could be applied to social infrastructure planning and development? The research results show that need analysis is generally linked to various methods, but for the SI planning, development and implementation specifically, there are certain methods, the application of which depends on specifics of rural areas (as territory) and features of local community.
\end{abstract}

Key words: rural social infrastructure, rural area, rural community, needs assessment methods

Santrauka: Šiame straipsnyje analizuojami poreikių kaimo socialinès infrastruktūros paslaugoms tyrimo metodai. Kaimo socialinè infrastruktūra yra svarbus kaimo vietovių gyvavimo elementas ir ji apibūdinama ìvairiai: socialinè ekonominè sistema, pagrindinès paslaugos teikiamos vietos bendruomenei, "socialinis tiltas" ivvairių socialinių grupiụ integracijai į visuomenę skatinti, faktorius lemiantis žmogiškujų poreikių patenkinimą ir žmogiškujų teisių užtikrinimą. Be minètos socialinès infrastruktūros svarbos kaimo vietovėms ir kaimo bendruomenei, išryškèja ir poreikių kaimo socialinės infrastruktūros paslaugoms tyrimo metodų identifikavimo apribojimai/stoka mokslinèje literatūroje. Šio tyrimo tikslas yra išanalizuoti poreikių kaimo socialinès infrastruktūros paslaugoms tyrimo metodus. Atliekant tyrimą keliamas ir nagrinėjamas šis probleminis klausimas: kokie skirtingi poreikių kaimo socialinès infrastruktūros paslaugoms tyrimo metodai gali būti taikomi planuojant socialinès infrastruktūros pokyčius ir plètros galimybes? Tyrimo rezultatai atskleidè, kad îvairūs tyrime išanalizuoti poreikių tyrimo metodai yra svarbūs, tačiau, igyvendinant socialinès infrastruktūros pokyčius, dėmesys dažniau fokusuojamas i keletą metodų, kurie priklauso nuo tokių esminių faktorių kaip kaimo vietovès (kaip teritorijos) specifiškumas ir kaimo bendruomenès bruožų.

Raktiniai žodžiai: kaimo socialinè infrastruktūra, kaimo vietovè, kaimo bendruomenè, poreikių nustatymo metodai

\title{
1. Introduction
}

Structural changes of rural areas in Lithuania are linked to various social economic and political legal aspects. Rural area viability is no longer intensive due to a variety of reasons, of which the most common reasons referred to are: population decrease, rural to urban migration or international migration, increase in the number of social risk groups under the similar pattern, and complicated prevention of poverty and social exclusion, inadequate possibilities to meet rural residents' needs, increasingly difficult availability and accessibility of social infrastructure (SI) services. According to the Department of Statistics of the Republic of Lithuania (Statistical yearbook of Lithuania, 2016), Lithuanian population living in rural areas amounted to 33 percent in 2016 , or $5.3 \%$ less than in 2012 . Changes in the rural population in the last decade (2016 compared to 2005) have led to decrease in rural population by $15.7 \%$. This population decreasing trend is usually related to the decreasing number of births, large internal and external migration flows to another rural or urban areas, insufficient provision of basic services. Moreover, $1.5 \%$ decrease in the number of rural settlements in 2016 as compared to 2005 has been identified during registration of rural area changes (Demographic Yearbook, 2015). This prompts the need 
to reconsider the specifics of rural people's living environment, its planning and development related to social infrastructure services.

The level of material need satisfaction is traditionally and increasingly subject to assessment in the context of immaterial needs, i.e., by considering human well-being as a whole, level of health, securing human rights, possibilities and possibilities of choice, as emphasised in a number of different strategic documents of the EU, research reports, and in public domain. SI services and perception of their benefit are based on identification of the appropriate methods for determination of the respective needs. Authors in this article follow this definition of rural social infrastructure as it is a territorial and spatial system of interrelated types of economic and social activity and relations creating conditions for functioning of ecosystems, creation of physical and social capitals used by the individuals and communities to satisfy individual and social needs (Atkočiūnienè et al., 2014). Broader concept of SI is given by A. Yessengeldina et al. (2014), where SI is characterised by features of settlement, production and labour, the economic mechanism, its formation and operation, and other properties as a social and territorial subsystem of society. This and other definitions are not always related to needs satisfaction issue or moreover methods for analysing the needs for SI services. The RSI situation, its planning and development are usually associated with such sectors as education, training, consultancy; communications and telecommunications; utilities and municipal services; transportation; culture, sports, and recreation; trade and public catering services; health and social security, and personal and property protection. Considering the fairly wide variety of SI services and methods for determination of the needs for such services that depend on their goals and applicability - to a territory, organisation, social group, addressing an issue, etc., determination of residents' needs for SI services could be claimed to be one of the areas of the study on respective needs. However, residents are not always the target group that determines the SI services to be provided in the rural area and method of their provision. In view of the above, the main aim of the methods for assessment of the needs for social infrastructure is to provide "useful feedback" to a variety of local primary intended users (Watanabe, 2007; Teriman et al., 2010; Kondrotaite, 2012) (local people) and other actors (organisations), including local action groups, local government, farmers, municipalities, relevant actors of private and NGO sectors who make decisions or seek information about analysed issue. It should be noted that SI services and the need for them are not discussed widely in the Lithuanian social science, and this research therefore has both scientific and practical purpose.

In scientific literature, the following methods for determination of the needs for SI services are usually acknowledged: local people surveys, surveys/interview of clients/consumers visiting the area, interview of specialists/experts, description of SI objects in the rural area (including statistical analysis of secondary data, census), note-taking templates, visual methods (such as photo/video methods), focus group method, evaluation of local organisations (e.g., municipality, eldership, local action groups) activity reports. This article presents the example of the method for assessment of social infrastructure needs in Lithuania: questionnaire and its features, which is the most common method employed in order to obtain information from a large number of residents.

Research object: methods for assessment of rural social infrastructure needs.

Research aim: to analyse the methods for assessing the needs of rural social infrastructure.

Research objectives: 1) to analyse the theoretical aspects of importance of need assessment for rural social infrastructure development; 2) to describe the possibilities to apply for need assessment methods of rural social infrastructure; 3 ) to present a case study results based on the need assessment methods for application for social infrastructure in Lithuania.

Research methods: analysis and synthesis of the scientific and secondary literature, comparison method, case study, graphic depiction.

The findings of the research are presented as follows: first, the situation and discussions on the importance to assess the needs for social infrastructure development are provided; further, research methodology is described; afterwards, the methods for assessment of needs for rural social infrastructure services are analysed; finally, the insights into a case study identifying the needs for SI services in Lithuania are presented. 


\section{Theoretical background}

Under the theory of hierarchy of needs, higher and lower level of needs are identified. Needs are one of the key motives that determine consumption. According to expert assessment data by the Department of Statistics of Lithuania, rural residents' social needs are one of the strongest factors of rural social development (Allison, 2000; Socialinès apsaugos..., 2004). At present, however, satisfaction of rural residents' need is not the key criterion in rural social development related to decision making. The studies conducted and data published by the Department of Statistics of the Republic of Lithuania provide clear evidence that rural social institutions are unable to go hand in hand with the changing life and rural residents' needs under the conditions of rapid reorganisation of public political, economic and cultural life in Lithuania. The quantity and quality of social services offered in rural areas do not correspond to the requirements set by the majority of rural residents.

Rural residents' needs for SI services may be referred to as local residents' social needs. L. Marcinkevičiūtè and R. Petrauskienè (2007) have employed the following techniques for assessment of the need for social services in rural areas and general social indicators (demographic characteristics of the community, social-economic indicators, health and education level, housing, family structure, security, etc.):

1) social survey among the community members in order to identify residents' characteristics, needs and desires using the questionnaires, phone and in-person interviews;

2) survey among the social service providers in order to identify the services provided within the community, the number of service recipients, their structure, etc.;

3) open meetings of the community in order to identify the need for services and priorities of their development;

4) expert survey among the local community leaders, public organisations and social work organisers.

According to R. F. Baumeister and M. R. Leary (1995), A. Guide... (2008), M. Engle and J. W. Altschuld (2014) the need should be primarily observed; under any conditions, the need should act on the thinking, feelings and behaviour; in case the need is not satisfied, negative consequences should be observed. Where the need is not satisfied, its objective importance should either increase or decrease. The authors have also noted that the needs should be common for everyone.

L. Kulbickienè (2004) believes that needs reflect residents' orientations and choices, i.e. the existing services sought and the services that satisfy them. On the other hand, the existing SI services shape and act on the needs that, in turn, reflect the demand for non-existent or difficult to access services. Such coordination of the supply and demand of needs for SI services provides better insight into characteristics of social and economic differentiation of rural residents.

It should be noted that increasing consumption of services provided in rural areas or the residents' expressed need for a non-existent service or goods are one of the more important conditions of development of rural SI. Hence, local residents' behaviour and need for public services depend on a number of different factors related not only to cultural, economic and social situation, but also to psychological factors such as motives, personality, perception, attitudes, experience, etc. J. Bivainis, N. Vilkaite (2010) have identified the factors that determine local residents' satisfaction: expectations related to product price, assortment, unique character, convenience, reliability, quality, value provided, accessibility, reliable information about the product, etc.

According to K. Zikienè (2009), rural residents' wishes and needs are not stable: a consumer may shift to another alternative service provider every time before making the decision on purchasing an appropriate goods or services. Nonetheless, considering territorial distribution of the rural SI objects, in particular, in rural areas, a consumer experiences greater discomfort when opting for an alternative than in the case of services in urban territories. This is usually related to time and financial resources. Hence, SI objects should perform efficient planning, organisation, implementation, and control over consumer attraction. 
SI management requires high level of professionalism and innovation from the rural development actors. SI composition differs depending on the rural area and is unique. As a result, organisations that generate and arrange for SI services create the supply of RSI services, while rural communities create the demand. Rural community needs are one of the prerequisites for alignment of RSI supply and demand. Distance, quality, price and flexibility - related inconsistency between RSI supply and demand determines more inferior access of RSI services to rural residents. Therefore, considering place-based specificities, there are various methods for determination of needs for such services.

The main goal of $\mathrm{SI}$ is satisfaction of rural residents' needs and compliance with the community priorities (Baumeister, Leary, 1995; Teriman et al., 2010; Infrastructure..., 2014; Vaznonienè, 2015). The concept of needs for the SI services could be interpreted in different ways. The basic and the most general approach of needs for the SI services reveals that these services (such as education, health and social care, security, transport, post etc.) are used very often and satisfy substantial and the everyday needs of a person. The National Infrastructure Plan (Infrastructure..., 2014) report defines infrastructure as the fixed, long-lived structures that facilitate the production of goods and services and underpin many aspects of quality of life. It has been widely acknowledged that social infrastructure is essential for health, well-being and economic prosperity of communities. It must be noted that the social infrastructure concept itself goes beyond a simple categorisation of physical infrastructure and be considered as soft infrastructure that gives a role for social capital and capacity building in order to increase the level of social infrastructure services quality, accessibility and compliance with people's needs (Gabdrakhmanov, Rubtsov, 2014).

Access to social infrastructure services enables people to take advantage of economic opportunities and access markets, jobs, information and training. Provision of social infrastructure services is also central to achieving economic development and providing poor people with opportunities to escape poverty and social exclusion (Social..., 2007; DFID, 2013; Yessengeldina et al., 2014; DFID, 2015). Development, proper distribution of SI services may strengthen the image of less attractive areas and create more comfortable life for local residents. Moreover, proper distribution of SI objects activates community service as the trigger for community activity and promotes community flexibility. Development of local infrastructure gathers and unites both the residents and the activities (Atkočiūnienè et al., 2014). This leads to closer relations established between local residents and incoming visitors, i.e. the development of the network of SI service users.

SI services create positive social and economic effects. It therefore could be asserted that the research on the need for SI services is yet another opportunity to determine the SI services that the residents lack. Identification of SI services not only reveals the shortages experienced by residents, but also the performance of existing SI institution and quality of the services provided. Moreover, information on the needs for SI services not only applies to current local residents, but also enables developing forecasts related to population change, which would make respective influence on the future level of development of SI services.

Needs are usually understood as the gap between present situation (what is now/real situation) and future expectations (what should be/ideal situation) (Alison, 2000). Rural social infrastructure needs analysis has therefore been understood as an assessment of the demand for services and facilities (Weber et al., 2016). Need analysis serves for different SI assessment purposes. Identification of needs is a process of describing "problems" of a target population and possible solutions to these problems. The need analysis, accordingly, focuses on the future, or what should be done, rather than on what was done. Analysis of different literature (A Guide..., 2008; Infrastructure..., 2014; Vaznoniené, 2015) allows to explore the types of information and possible results of need assessment research (Fig. 1.). 


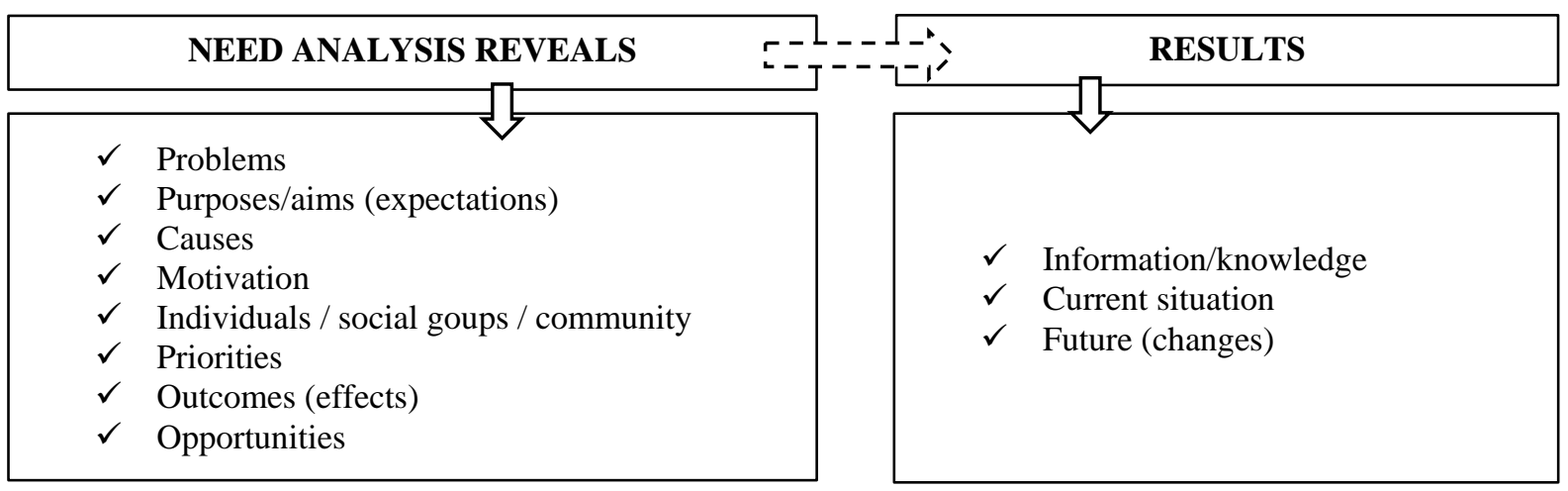

Fig 1. Types of information and possible results of need assessment research (developed by the authors).

As demonstrated in the table, results depend on the researchers' aims prior to the research. Need analysis could be claimed to provide and give new or supplementary information/knowledge about $\mathrm{SI}$, describe the present situation with positive insights and existing disadvantages, and provides future guidelines - what should be expected or done to improve the situation.

In view of the above, need identification is also often focused on its assessment methods. It should be noted that both objective and subjective assessment of needs is employed, which often determines the methods chosen for research of the needs. Subjective vs. objective assessment (demands (priorities) vs. statistics) is construed as the benefit of subjective assessment in parallel to assessment of the objective situation (Social..., 2007; A Guide..., 2008 Ahgren et al., 2009; Kondrotaite, 2012; Yessengeldina et al., 2014; Engle, Altschuld, 2014). Hence, the benefit of subjective assessment in RSI context becomes one of the key factors determining the supply and demand for RSI services by:

- providing information on what rural residents find to be important rather than taking into account objective conditions only;

- revealing different degree of development of residents' needs and the directions of their satisfaction;

- revealing different social groups' attitudes towards RSI;

- revealing rural residents-consumers' opinion on the demand for RSI services;

- revealing residents' priorities that contribute to improvement of the quality of life and wellbeing;

- showing the importance of social relations in satisfying the needs, promoting social integration and participation;

- $\quad$ showing the current and future priorities of RSI development solutions;

- helping to identify innovative methods for addressing the issues and enabling to determine specific measures for addressing the issues;

- complements the data of past quantitative studies;

- promoting social coherence to focus the efforts of actors from different sectors on improvement of SI.

Social infrastructure planning report (2007) asserts that the type of needs should be considered (Table 1). 
Tab 1. A Framework for Understanding Need (Social..., 2007).

\begin{tabular}{|l|l|l|}
\hline \multicolumn{1}{|c|}{ Types of need } & \multicolumn{1}{|c|}{ Description } & \multicolumn{1}{c|}{ Information source } \\
\hline Felt need & $\begin{array}{l}\text { What people say } \\
\text { they } \\
\text { need }\end{array}$ & $\begin{array}{l}\text { Feedback from consultation with the community and } \\
\text { facility/service providers (e.g. through meetings, forums, } \\
\text { interviews, other) }\end{array}$ \\
\hline Expressed need & Actual demand & $\begin{array}{l}\text { Measured through waiting lists, number of requests for } \\
\text { services (e.g. through facilities inventory survey) }\end{array}$ \\
\hline Normative need & $\begin{array}{l}\text { Expert analysis of } \\
\text { need }\end{array}$ & $\begin{array}{l}\text { Investigated through demographic and social trends } \\
\text { analysis }\end{array}$ \\
\hline $\begin{array}{l}\text { Comparative } \\
\text { need }\end{array}$ & $\begin{array}{l}\text { Comparable rates of } \\
\text { provision }\end{array}$ & $\begin{array}{l}\text { Comparative assessment of existing rates of supply against } \\
\text { common rates of provision in other similar communities }\end{array}$ \\
\hline Latent need & $\begin{array}{l}\text { Needs that users are } \\
\text { not yet aware of }\end{array}$ & $\begin{array}{l}\text { Demographic analysis, particularly of population change } \\
\text { and growth Analysis of research and public/ social policy }\end{array}$ \\
\hline
\end{tabular}

Both the community profile and the inventory of facilities provide data needed to conduct a spatial analysis of need. Planning further steps in consideration of SI improvement is easier following clarification of the type of needs that are relevant to particular community. Authors of the article have noted that the methods for determination of needs are also related to applicability of the research results. The issue discussed above provides possibilities for demonstration and validation of the needs for SI services in the scientific and practical aspect (Table 2).

Tab 2. Scientific and practical validation of assessment of needs for social infrastructure services (made by the authors).

\begin{tabular}{|c|c|}
\hline $\begin{array}{r}\text { infr } \\
\text { sclentic ve }\end{array}$ & \\
\hline $\begin{array}{l}\text { - Factors attracting and repelling RSI services; } \\
\text { - identifies the needs of different generations and social } \\
\text { groups; } \\
\text { - identifies the priorities of current and future priorities } \\
\text { of solutions for RSI development; } \\
\text { - ensures comprehensive analysis of location-specific } \\
\text { SI issues; } \\
\text { - complements the data of past studies } \\
\text { (cognitive/information dissemination function); } \\
\text { - attractiveness of the questionnaire as a method in the } \\
\text { study on needs - correspondence to specific location } \\
\text { (possibility to amend, add questions in view of the } \\
\text { situation of locality N), change of social economic, } \\
\text { demographic situations, presence of other external } \\
\text { factors, possible change in residents' judgement; } \\
\text { - classification of residents' needs becomes relevant; } \\
\text { - statistical conclusions (opinion of the majority of } \\
\text { residents) are more important in assessment of } \\
\text { development prospects of } \mathrm{N} \text { territory compared to } \\
\text { remarks by individual respondents; } \\
\text { - reasonableness of the sample size; } \\
\text { - assessment of services by identification of their } \\
\text { quality, flexibility in provision, accessibility, availability } \\
\text { principles. }\end{array}$ & $\begin{array}{l}\text { - Main SI goal is satisfaction of rural } \\
\text { residents' needs and compliance with } \\
\text { the community priorities; } \\
\text { - rural residents' needs are one of the key } \\
\text { factors determining the supply and demand } \\
\text { for RSI services; } \\
\text { - the existing SI services shape and influence } \\
\text { the needs that, in turn, reflect the demand } \\
\text { for non-existent, difficult to access services; } \\
\text { - the existing SI objects help identify wider, } \\
\text { additional possibilities for their application; } \\
\text { - social links are strengthened / networks } \\
\text { between SI institutions are established; } \\
\text { - residents' social inclusion and cohesion } \\
\text { between different localities are promoted; } \\
\text { - skills and competences of persons } \\
\text { providing the services are strengthened; } \\
\text { - competitive advantages and limitations of } \\
\text { the rural area become evident; } \\
\text { - the importance of time and material costs; } \\
\text { - assessment of availability and accessibility } \\
\text { of social infrastructure services. }\end{array}$ \\
\hline
\end{tabular}

Scientific and practical applicability of the research results also reveals the level that $\mathrm{SI}$ issues local, regional or national - could be addressed on. This also depends on the scope of SI issues and possibilities to deal with them on the local level. Scientific validation of research of SI needs expands the knowledge on local SI issues and possibilities, provides information on possible new 
developments. Practical justification of the needs for SI services, initiatives on changing the situation are indicated by various local actors who are immediately related to their living environment.

As stated in the Social infrastructure planning (2007) report, implementing the guidelines on conversion of needs into infrastructure provision can be complicated. Specifics of every rural area naturally determines and causes certain limitations in research of needs for SI services (Atkočiūnienè et al., 2014):

- the need for SI changes is not visible, not expressed or not perceived;

- individual rural residents have specific needs, but the rural community has its own goals and needs - the issue of which of them are more important emerges;

- inadequate knowledge of facility co-location and/or the appropriateness of doing so;

- questions should be formulated in view of the target group participating in the research;

- not all future respondents are easy to access or wish to be part of the research;

- respondents may omit certain questions due to lack of competence;

- conclusions are applicable only to generalisation of $\mathrm{N}$ district residents' opinion and not applicable to assessment of other district residents' opinions on the possibilities for strategic development of the districts;

- expression of questions "average", "difficult to answer", "I don't know" and specifics of open questions.

Summarising the insights into the importance of assessment of needs for rural SI development, this kind of research demonstrates multiple benefits. First, most of the literature emphasises knowledge which can be disclosed about current needs and characterises local resources and opportunities useful for the changes. Besides the discussed scientific and practical benefit of need assessment importance for rural SI development, there is also a possibility for commercial activity. This means that being aware of the lack of certain SI services in rural area, in particular, where there is imbalance of supply and demand in public sector, private initiatives may help improve the situation, if there is a need for this kind of services.

\section{Research methodology}

The background of this research is based on two-fold steps. Firstly, descriptive analysis and comparative method for analysis of methods for assessment of needs for SI services are applied by using scientific literature and insights from empirical reports findings. This has allowed the authors to reveal the most common or innovative methods for assessment of needs for SI in rural areas. Secondly, the example of Lithuanian case is presented (described in more details in scientific study (Atkočiūnienè et al., 2014)). The case study is substantiated by previous empirical research in five pilot rural areas related to SI improvement in Lithuania, already practiced from time to time. Application of the questionnaire method for identification of needs for SI services could serve as a good practice example, in particular, where it includes various SI sectors and their elements, or just particular SI sector.

\section{Results and discussion}

\subsection{Application of needs assessment methods to rural social infrastructure}

Participation in SI planning refers to opportunities for stakeholders to contribute and influence planning processes and outcomes. It should be emphasised that involvement and participation of various actors in SI planning and development process implies different steps related to particular method. Some insights related to need assessment methods are given in Table 3.

Photovoice is a method for a researcher to identify, represent, and enhance their community thoughts using a specific photographic technique. Under this method, people are given video cameras to enable them to act as recorders and potential catalysts for change, in their own communities. It uses the immediacy for the visual image to furnish evidence and to promote an effective, participatory means of sharing expertise and knowledge (Wang, Burris, 1997).

Tab 3. Advantages and disadvantages of needs assessment methods (made by authors). 


\begin{tabular}{|c|c|c|c|}
\hline Source & Methods & Advantages & Disadvantages \\
\hline $\begin{array}{l}\text { Social } \\
\text { infrastructure } \\
\text { planning } \\
(2007)\end{array}$ & $\begin{array}{l}\text { Surveys; } \\
\text { interview; focus } \\
\text { group meetings, } \\
\text { Delphi method, } \\
\text { working groups; } \\
\text { workshops }\end{array}$ & $\begin{array}{l}\text { Questionnaire surveys are a rather subjective } \\
\text { method for assessment of local residents' } \\
\text { needs. Atthough the researcher receives } \\
\text { answers to specific questions, the answers to } \\
\text { closed-ended questionnaire questions do not } \\
\text { reveal the respondents' true attitude towards } \\
\text { the issue analysed, and the research results } \\
\text { may be interpreted differently. } \\
\text { Interview, Focus group meetings, Delphi } \\
\text { method and direct contact with the respondents } \\
\text { always provide positive results, as the } \\
\text { researcher may deepen a question, ask to } \\
\text { specify the answers and to provide comments } \\
\text { on the issues of interest to him/her. }\end{array}$ & $\begin{array}{l}\text { In case of a questionnaire survey, there is } \\
\text { always a risk of omitting essential } \\
\text { attributes, consequences of the } \\
\text { situation/phenomenon analysed, etc. } \\
\text { A questionnaire must be designed with } \\
\text { a high level of professionalism for } \\
\text { the respondent to feel comfortable in } \\
\text { completing it. This method is fairly time- } \\
\text { and cost-intensive. Methods of need } \\
\text { analysis requiring direct contact with } \\
\text { a respondent may be risky due to } \\
\text { researcher's poor preparedness for } \\
\text { the research, violation of the principles of } \\
\text { research ethics. }\end{array}$ \\
\hline $\begin{array}{l}\text { Ahgren et al. } \\
\text { (2009); } \\
\text { Atkočiūnienè } \\
\text { (2014); }\end{array}$ & $\begin{array}{l}\text { Analysis of } \\
\text { secondary data } \\
\text { based on SI } \\
\text { services; } \\
\text { questionnaire } \\
\text { method }\end{array}$ & $\begin{array}{l}\text { Analysis of secondary data is considered to be } \\
\text { a reliable method of data analysis merely for } \\
\text { the reason that the statistical or other } \\
\text { information gathered has already been verified } \\
\text { by the subjects providing the information. This } \\
\text { saves the researcher's time. An additional } \\
\text { questionnaire for analysis of the } \\
\text { phenomenon/issue under analysis would } \\
\text { complement the secondary data analysis with } \\
\text { more recent, more subjective data. }\end{array}$ & $\begin{array}{l}\text { Secondary data are not always the most } \\
\text { recent to reflect the true current } \\
\text { challenges. Larger share of statistical } \\
\text { information, in particular, on the lower } \\
\text { level of local self-government, is not } \\
\text { gathered, and it is difficult to compare } \\
\text { local residents' needs, standards of living } \\
\text { and quality of senices in terms of their } \\
\text { gap from urban centres. }\end{array}$ \\
\hline $\begin{array}{l}\text { Wang. Burris } \\
\text { (1997) }\end{array}$ & $\begin{array}{l}\text { Photovoice for } \\
\text { participatory } \\
\text { needs } \\
\text { assessment }\end{array}$ & $\begin{array}{l}\text { The method enables people to reflect their } \\
\text { community strength and concems, promotes } \\
\text { critical dialogue and knowledge about important } \\
\text { community issues through large and small } \\
\text { group discussion of photograph and decision } \\
\text { makers. }\end{array}$ & $\begin{array}{l}\text { If used on its own, the method is not } \\
\text { capable of reflecting all local residents' } \\
\text { issues related to the question under } \\
\text { analysis and depends largely on } \\
\text { the researcher's, photographer's } \\
\text { attitudes, ability to notice and interpret. It } \\
\text { would therefore be more efficient to use } \\
\text { this method in combination with other } \\
\text { research methods that complement } \\
\text { the research results. }\end{array}$ \\
\hline $\begin{array}{l}\text { Lewin (1946); } \\
\text { Rappaport } \\
\text { (1990) }\end{array}$ & $\begin{array}{l}\text { Action research } \\
\text { approach to } \\
\text { evaluation }\end{array}$ & $\begin{array}{l}\text { The method is valuable in that the researcher } \\
\text { and the research participant participate in } \\
\text { solving the issues and/or discussing the } \\
\text { questions of interest to the researcher. Direct } \\
\text { contact and participation create the synergy of } \\
\text { research results by integrating the knowledge, } \\
\text { expertise and experience (at present) and } \\
\text { assessing possible consequences. }\end{array}$ & $\begin{array}{l}\text { The method is not appropriate for } \\
\text { analysing the needs of general public. } \\
\text { The method is the most appropriate for } \\
\text { analysing issues related to quality of life of } \\
\text { small, in particular, social groups. }\end{array}$ \\
\hline Israel (1985) & $\begin{array}{l}\text { Natural } \\
\text { helper } \\
\text { interventions; } \\
\text { one-to-one } \\
\text { process } \\
\text { consultation } \\
\text { approach for } \\
\text { developing a } \\
\text { relationship and } \\
\text { providing } \\
\text { service; a } \\
\text { combination of } \\
\text { consultation and } \\
\text { training }\end{array}$ & $\begin{array}{l}\text { The method is valuable in that the researcher } \\
\text { and research participant participate in solving } \\
\text { the issues and/or discussing the issues of } \\
\text { interest to the research. Direct contact and } \\
\text { participation create the synergy of research } \\
\text { results by integrating the knowledge, expertise } \\
\text { and experience (at present) and assessing } \\
\text { possible consequences. These methods are } \\
\text { also valuable in that the researcher may } \\
\text { observe the research participant's behaviour } \\
\text { and emotions during discussion on the } \\
\text { research questions. Research participants often } \\
\text { do not perceive the scope of issue, or the } \\
\text { researcher misinterprets it, and application of } \\
\text { such research methods may help receive } \\
\text { answers to all questions of interest. }\end{array}$ & $\begin{array}{l}\text { The method is not appropriate for } \\
\text { analysing the needs of general public. } \\
\text { The method is the most appropriate for } \\
\text { analysing the needs of small, in particular, } \\
\text { social groups. Researcher's high level of } \\
\text { competence related to consulting and } \\
\text { psychology is required in application of } \\
\text { these methods. Application of the method } \\
\text { in a quality manner requires a great deal } \\
\text { of preparation, considerable time input, as } \\
\text { several meetings with the same research } \\
\text { participants are often required. }\end{array}$ \\
\hline
\end{tabular}


Action research, which was first described by K. Lewin in 1946. J. Rappaport (1990) has made the most clearly articulated call for an action research approach to understanding what community empowerment and its effects are. His argument centres on how to conduct research rather than on what to study; confronting the disempowering nature of assumptions, responsibilities, and values reflected in traditional methods of data collection and analysis. Within the theological framework for naturalistic evaluation in educational settings, J. Rappaport proposes criteria for determining trustworthiness of qualitative findings (comparable to validity and reliability in quantitative methods) and the research methods' authenticity to the empowerment process.

There are numerous examples, where the main focus has been put on strengthening networks by working with natural helpers. Most frequently, a set of criteria is established to describe the characteristics/type of person that fits the research definition of a natural helper. Various terms are used, e.g., "health facilitator", "natural neighbour". In the beginning, the research frequently involves participant observation and informal interviews for diagnosis of the target area, including the nature of network interactions. In certain research works, a formal, closed-ended question survey is carried out among the residents to identify needs. Certain research works focus on professionally identified needs as defined by census data, evidence, and similar sources of information (Israel, 1985). Moreover, the author has recommended using a one-to-one process consultation approach for developing a relationship and providing service between professionals and natural helpers. Others have relied upon training where natural helpers are brought together in a group of rural community. The varied content of such training includes specific instructions, information on the service delivery system, and developing skills of effective counselling. A combination of consultation and training also can be used as good methods for need assessment. Following this combination of different approaches to possible need assessment methods leads to particular steps of its implementation (Table 4).

Tab 4. Community participation in planning (developed by Social.., 2007).

\begin{tabular}{|l|l|l|}
\hline Planning step & Inputs to planning & Example methods \\
\hline Profiling & $\begin{array}{l}\text { Identifying capacity of social infrastructure; Identifying } \\
\text { local values and priorities; Commenting on } \\
\text { the adequacy of existing/proposed models of } \\
\text { infrastructure position }\end{array}$ & $\begin{array}{l}\text { Surveys, interviews, focus } \\
\text { groups, websites }\end{array}$ \\
\hline $\begin{array}{l}\text { Analysis and } \\
\text { assessment }\end{array}$ & $\begin{array}{l}\text { Input to assessment of type and scale of infrastructure } \\
\text { required; advocating priorities for local and regional } \\
\text { social infrastructure; defining problems and identifying } \\
\text { solutions; reviewing findings and providing input to } \\
\text { strategies }\end{array}$ & $\begin{array}{l}\text { Workshops, phone-in and } \\
\text { email comment; } \\
\text { interagency forums; think } \\
\text { tanks; working groups; } \\
\text { action research }\end{array}$ \\
\hline $\begin{array}{l}\text { Provision and } \\
\text { implementation }\end{array}$ & $\begin{array}{l}\text { Contributing to the development of locally and } \\
\text { regionally appropriate solutions; identifying } \\
\text { opportunities for integrating new facilities with existing } \\
\text { adjoining uses; identifying opportunities/interest un } \\
\text { joint development, design and use of new facilities, } \\
\text { such as community centres; evaluating and tracking } \\
\text { the effectiveness of local social infrastructure in } \\
\text { supporting community well-being }\end{array}$ & $\begin{array}{l}\text { Design works } \\
\text { days; reference groups; } \\
\text { charrettes; web-based } \\
\text { input, displays; } \\
\text { submissions; ongoing } \\
\text { information exchange }\end{array}$ \\
\hline
\end{tabular}

It should be mentioned that researchers have used knowledge pre- and post-tests for substantive training sessions on several occasions. It is recommended to ask natural helpers to keep records of help-giving interactions and to sometimes have conducted interviews with natural helpers regarding their help-giving interactions as well as satisfaction of the services, needs and etc.

Diversity of the research methods for identification of SI needs can enrich interpretation and lead to the conclusion that the choice of a research method depends on the scope of phenomenon analysed, i.e. research width and depth. It is important that the researcher first determines the level of research, then - the attributes of the issue/phenomenon under analysis, and afterwards integrates several need research methods. Classical research methods, such as mail, online surveys, surveys by visiting local residents, etc. are sufficiently informative and have been 
used for many years. However, innovative methods, such as photovoice or action research approach, may provide new approach, reveal panoramic overview, and view the issues analysed from a different angle. This may promote innovations, new ingenious insights.

In analysis and conversion of local community needs for SI planning and development requirements, it is important to follow the sequence of actions under different methods for need assessment applied in practice (Fig. 2). The authors present possible and already tested, but not the only example of this process of assessment of needs for SI, from theoretical to empirical action. The case implemented repeatedly has been related to application of questionnaire method.

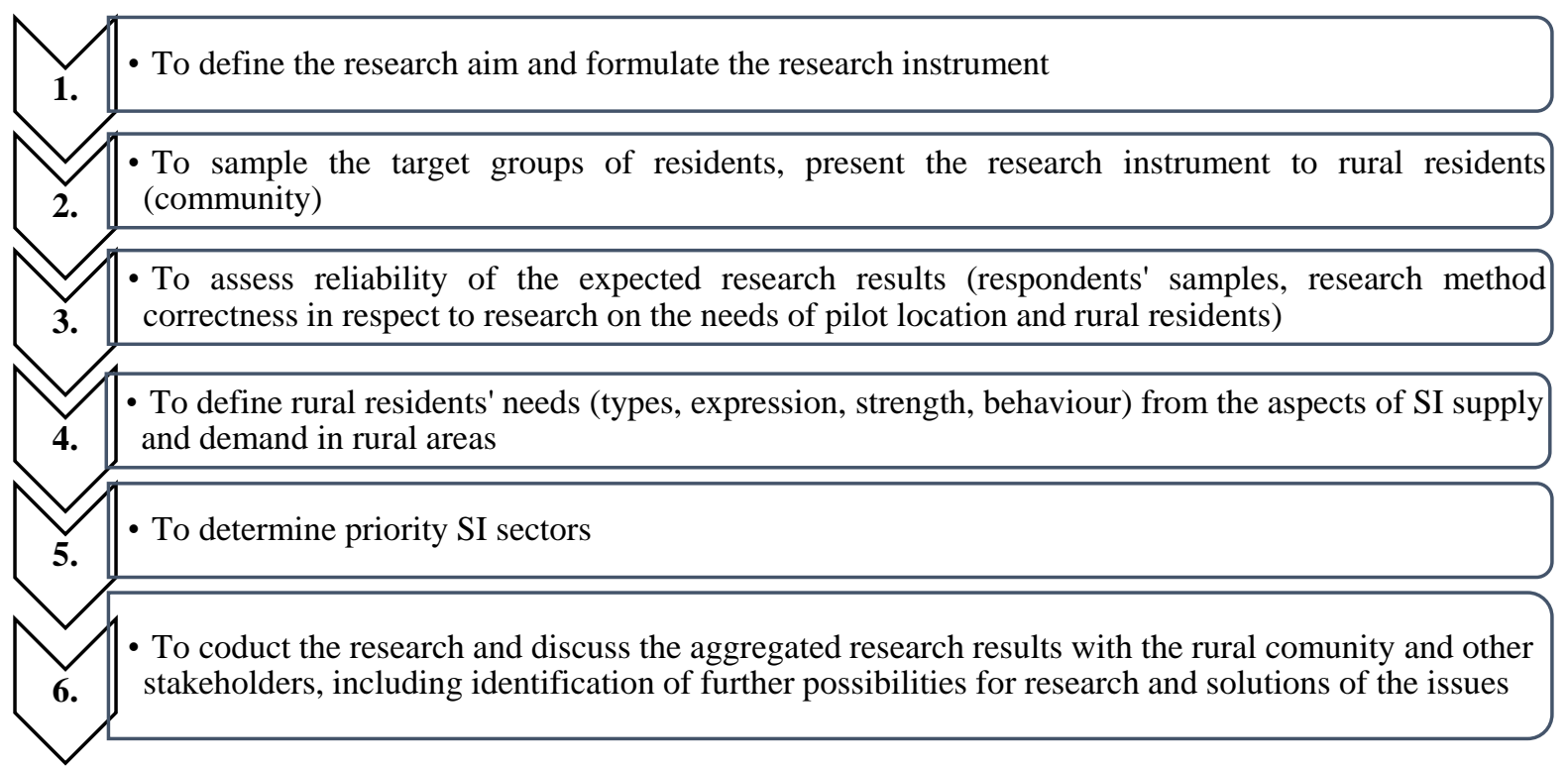

Fig 2. Logical scheme of assessment and analysis of needs for social infrastructure (made by the authors).

The example presented implies that these steps can be used interchangeably depending on the specifics of local area situation and its resources. It is worth noting that the beginning of need assessment depends on correctly substantiated need assessment instrument.

\subsection{Example of assessment of local community needs for SI on the basis of Lithuania case}

Authors of the paper have used the results of a completed research in order to determine the best and most convenient methods for research of residents' needs for SI services. The method of questionnaire survey as a subjective assessment is referred to as a traditional method for identification of needs, and the good practice of application of this research method in the SI context has been validated in reports of other research and practical works. The method of questionnaire survey allows to explore, identify, assess the scope, relevance, cause and effect relations of the issue analysed, identify the respondents' opinion on current state of RSI and existing shortcomings of the RSI objects and, in general, reveals the attractiveness/issues of the residential area that are relevant to local residents (Atkočiūnienè et al., 2014). Table 5 below presents typical social infrastructure sectors and their elements with respective aims of potential questions.

Besides the main questions that characterise the SI situation, traditional questions are often included and relate to: 1) respondents' social, demographic, economic characteristics; 2) assessment of issues of the residential area - the issue under analysis (in order to identify the existing issues in the area); identification of shortcomings of the residential area (in order to identify the shortage of particular SI objects/services and the SI objects/services that should be introduced into the pilot areas). All the questions enable the researchers to build a systemic approach towards the SI situation of the rural areas and respondents' views, reveals attractiveness of the residential area in terms of living, work, and investment. Questionnaire 
survey (of residents, experts) as a research toolkit, for the purpose of its versatility and applicability, could be claimed to be applicable to:

- all SI sectors (and their elements) on various territorial levels (local, regional, national);

- analysis of situation of a certain SI sector (e.g. of the demand for services of the respective sector according to residents' demographic characteristics, generations, etc.);

- analysis according to social, economic, territorial specifics of the area by introducing supplementary, territory-specific questions.

Tab 5. Elements of the questionnaire for assessment of needs for SI services (made by authors following Atkočiūnienè, 2000; Atkočiūnienè et al. 2014).

\begin{tabular}{|l|l|l|}
\hline \multicolumn{1}{|c|}{$\begin{array}{c}\text { Social } \\
\text { infrastructure } \\
\text { sectors }\end{array}$} & \multicolumn{1}{c|}{$\begin{array}{c}\text { Questions' aims for subjective evaluation } \\
\text { of SI }\end{array}$} & Examples of SI elements \\
\hline $\begin{array}{l}\text { General evaluation } \\
\text { of situation of the SI } \\
\text { sectors }\end{array}$ & $\begin{array}{l}\text { To determine the respondents' general views } \\
\text { towards the situation of SI objects in their } \\
\text { residential area }\end{array}$ & - \\
\hline $\begin{array}{l}\text { Education, training, } \\
\text { consultancy }\end{array}$ & $\begin{array}{l}\text { To determine the respondents' view towards } \\
\text { the services provided by education, training, } \\
\text { consulting and culture objects and their quality }\end{array}$ & $\begin{array}{l}\text { Kindergarten, school, } \\
\text { consulting service/consultant }\end{array}$ \\
\hline $\begin{array}{l}\text { Communications } \\
\text { and } \\
\text { telecommunications }\end{array}$ & $\begin{array}{l}\text { To analyse the respondents' view towards } \\
\text { activity of communications and } \\
\text { telecommunications sectors and the quality of } \\
\text { respective services provided }\end{array}$ & $\begin{array}{l}\text { Phone, post, bank branch, } \\
\text { Internet connection }\end{array}$ \\
\hline $\begin{array}{l}\text { Utilities and } \\
\text { municipal services }\end{array}$ & $\begin{array}{l}\text { To assess the utilities, municipal and trade } \\
\text { services }\end{array}$ & $\begin{array}{l}\text { Utilities company, water } \\
\text { supply, housing, hotel, bath, } \\
\text { hairdresser, repair service for } \\
\text { household appliances }\end{array}$ \\
\hline Transportation & $\begin{array}{l}\text { To analyse the respondents' view towards } \\
\text { activity of transportation and communication } \\
\text { sectors and the quality of respective services } \\
\text { provided }\end{array}$ & $\begin{array}{l}\text { Public passenger transport, } \\
\text { land/water roads }\end{array}$ \\
\hline $\begin{array}{l}\text { Trade and public } \\
\text { catering services }\end{array}$ & $\begin{array}{l}\text { To analyse the respondents' view towards } \\
\text { trade and public catering services, trade } \\
\text { objects, provision of respective services and } \\
\text { demand for them }\end{array}$ & $\begin{array}{l}\text { Shop, marketplace, catering } \\
\text { company }\end{array}$ \\
\hline $\begin{array}{l}\text { Health and social } \\
\text { security }\end{array}$ & $\begin{array}{l}\text { To analyse the respondents' view towards } \\
\text { health and social security services, the quality } \\
\text { of their provision }\end{array}$ & $\begin{array}{l}\text { Medical station, hospital, } \\
\text { general practitioner, social } \\
\text { service, day centre }\end{array}$ \\
\hline $\begin{array}{l}\text { To determine assurance of personal and } \\
\text { property protection in the pilot areas }\end{array}$ & $\begin{array}{l}\text { Fire service, police inspector, } \\
\text { municipal and household } \\
\text { waste collection company }\end{array}$ \\
\hline
\end{tabular}

In general, identification of a proper method applicable to research of needs for SI services in rural areas could be claimed to be necessary for several reasons: proper method allows to identify the needs of different generations and social groups, social links/network between institutions are strengthened, residents' social inclusion and cohesion between areas are promoted, skills and competences of persons providing the services are strengthened. A properly designed and validated research instrument may not only assess local residents' needs, but also reveal the causes of the situation, forecast possible consequences at, at the same time, possible solutions of certain issue. 


\section{Conclusions}

Competitive advantages of rural areas are determined by the profile of rural area, i.e. the structure and quality of economic, social, natural, environmental and, in particular, human resources available in the area. Potential new residents, investors, etc. find high standards of living to be highly significant. Hence, the level of development of SI in rural areas could be assessed in view of the local residents' needs for public services and higher quality of life.

Local residents' needs may be analysed on various levels - these can be daily needs and quality of services used by the residents on a daily basis and essential services. Needs for episodic and periodic services, i.e. those that are used by rural residents less often, but the need for them remains, may be analysed as well. The depth and width of research of the local residents' needs determines not only the level of needs analysed, but also the level of the analysis: community, eldership, municipality, region, etc. Analysis of area-specific residents' needs and trends is possible only if the level of development of the area is taken into account.

In choosing the methods for research of local residents' needs, it is important to clearly identify the result expected, classify the needs into groups, identify the target group of research participants and choose the appropriate research method to reveal the situation in the most detailed manner possible. Researchers and practitioners recommend integrating traditional and innovative need research methods to generate comprehensive information, unconventional research results of the highest quality possible and encouraging to explore the situation for solutions presenting a strategic breakthrough.

Following the findings from the empirical research, such advantages of researching the needs of SI in the future were identified: they highlight not only current but also future priorities in decision making related to SI improvement and development; it supplement the existing quantitative research databases as well as provide cognitive and spread of information functions to interested agents; methods for SI needs identification can be various but their selection is based on different criteria, related to rural area features and local community profile.

The presented case study from Lithuania has demonstrated that questionnaire survey is the SI need research method, which is the most common and easiest for the residents to understand. The presented method has already been validated by several research works (implemented time to time), and its application is targeted, as the information obtained is rather informative, provides knowledge on the state of an individual or specific sector, the related issues, and possibilities to change the situation.

From the theoretical and empirical parts there were identified such limitations of the research:

- the scientific background on this topic in Lithuanian context is quite limited so there are not much knowledge of what methods are the most suitable for assessing the needs for SI services;

- the confrontation arises when the need for the SI changes / innovations is understood just from one side of interested agents (from local community or local government etc.), because it affects the selection of proper needs assessment methods; accordingly, in some cases, the question arises whether it is important to implement the general or specific needs assessment methods for SI services;

- when questionnaire method is applied to the particular (concrete) district, rural area it means that the results should reveal the situation only about that territory and should not be applied to other territories;

- respondents (or target group) can have insufficient knowledge or competence to evaluate the level of SI situation and this thing is seen in their responses' forms (such as "hard to say", "do not know“, „average“); the survey, questionnaires with an open questions has a disadvantage in the authorship of ideas, that may be evaluated on their source, rather than on their merit;

- scientific and practical research results show that a simple survey method, in order to explore the needs of SI services is no longer enough. The society is becoming more attractive to innovative research and involvement methods to the SI development decisions making process. However, here the researchers and especially local governance bodies, face with 
a lack of qualification to obtain reliable empirical research data and to interpret it for the RSI sectors' development;

- nonproperly selected needs assessment method can be time-consuming and moneyconsuming.

\section{Academic references}

[1] Ahgren, B., Axelsson, S. B., \& Axelsson, R. (2009). Evaluating intersectoral collaboration: a model for assessment by service users. International Journal of Integrated Care 9(1). DOI: $10.5334 / \mathrm{jic}$.304.

[2] Atkočiūnienè, V. (2000). Lietuvos kaimo socialinè infrastruktūra; ekonominis vertinimas ir plètra [PhD. Theses]. Kaunas: Aleksandras Strulginskis University.

[3] Atkočiūnienè, V., Aleksandravičius, A., Kiaušienè, I., Vaznonienè, G., Pakeltienè, R. \& Lukè, R. (2014). Kaimo socialinès infrastruktūros vystymasis siekiant užtikrinti teritorinę ir socialinę sanglaudą: mokslo studija Kaunas: Aleksandro Stulginskio universitetas.

[4] Bivainis, J. \& Vilkaitè, N. (2010). Vartotojų lojalumo nustatymo metodinio potencialo analizè. Verslas: teorija ir praktika, nr. 11(1), 49-60.

[5] Baumeister, R. F. \& Leary, M. R. (1995). The need to belong: Desire for interpersonal attachement as a fundamental human motivation. Psychological Bulletin 117(3), 497-529. DOI: $10.1037 / 0033-2909.117 .3 .497$.

[6] Engle, M., \& Altschuld, J. W. (2014). Needs assessment: The perspective from the public sector. In J. W. Altschuld \& R. Watkins (Eds.), Needs assessment: Trends and a view toward the future. New Directions for Evaluation (pp. 33-45). Hoboken, NJ: Wiley.

[7] Israel, B. (1985). Social Networks and Social Support: Implications for Natural Helper and Community Level Interventions. Health Education Quarterly, 12(1), 65-80. DOI: $10.1177 / \overline{109019818501200106 .}$

[8] Gabdrakhmanov, N. K. \& Rubtsov, V. A. (2014). The Objects of Social Infrastructure in the Social Image of the Region Shaping. Procedia - Social and Behavioral Sciences. 140, 419-421. DOI: 10.1016/j.sbspro.2014.04.446.

[9] Kondrotaitè, G. (2012). Evaluation of the quality of public services in Lithuanian municipalities. Intellectual Economics 6, (3), 393-411.

[10] Kulbickienè, L. (2004). Lietuvos gyventojų kultūriniai poreikiai: kultūros įstaigų vertinimas ir lankymas. Sociologija. Mintis ir veiksmas 8(2), 64-71.

[11] Lewin, K. (1946). Action-research and minority problems. Journal of Social Issues 2(4), 3446. DOI: 10.1111/j.1540-4560.1946.tb02295.x.

[12] Marcinkevičiūtè, L. \& Petrauskienè, R. (2007). Socialinių paslaugų teikimo tobulinimo aktualijos kaimiškose seniūnijose. Viešoji politika ir administravimas. 27, 28-37.

[13] Rappaport, J. (1990). Research methods and the empowerment social agenda. In Tolan, P., Keys, C., Chertok, F. \& Jason, L., eds, Researching Community Psychology (pp. 51-63). Washington, DC: American Psychological Association. DOI: 10.1037/10073-005.

[14] Teriman, S., Yigitcanlar, T. \& Mayere, S. (2011). Social infrastructure planning and sustainable community: example from south east Queensland, Australia. In: Jahan, N., ed., Proceedings of the Business and Social Science Research Conference 2011 (pp. 1-12). Melbourne: World Business Institute Australia.

[15] Vaznonienè, G. (2015). The role of rural community enhancing rural social infrastructure changes. Research for Rural Development. International Scientific Conference Proceedings (Latvia) 2, 176-182. 
[16] Yessengeldina, A., Sitenko, D. \& Seitalinova, A. (2014). The Development of Social Infrastructure in Kazakhstan. Public Policy and Administration. 13(2), 222-231. DOI: 10.13165/VPA-14-13-2-03.

[17] Zikienè, K. (2009). Vartotojų lojalumas: pakeitimo elgsenos formavimo modelis. Vadybos mokslas ir studijos - kaimo verslu ir ju infrastruktūros plètrai, 18(3), 89-97.

[18] Wang, C. \& Burris, M. A. (1997). Photovoice: Concept, Methodology and use for participatory needs assessment. Health education and behavior 24(3), 369-387. DOI: $10.1177 / 109019819702400309$.

[19] Weber, B., Alfen, H. W. \& Staub-Bisang, M. (2016). Infrastructure as an Asset ClassInvestment Strategy, Sustainability, Project finance and PPP. Hoboken, NJ: John Wiley \& Sons.

Other sources

[20] A Guide for Comprehensive Needs Assessment (2008). Albuquerque: Southwest Comprehensive Center at WestEd. Available at (online access 201701 18): https://www.cde.state.co.us/sites/default/files/documents/fedprograms/dl/consapp_na_guid e.pdf.

[21] Demographic Yearbook 2015. (2016). Vilnius: Statistics Lithuania.

[22] DFID (2013). Connecting People, Creating Wealth: Infrastructure for economic development and poverty reduction. London: DFID.

[23] DFID (2015). Sustainable infrastructure for shared prosperity and poverty reduction: A policy framework. London: DFID. Available at (online access 201701 16): https://www.gov.uk/government/uploads/system/uploads/attachment_data/file/398543/Infra structure-policy-framework-summary.pdf.

[24] Infrastructure Analysis to inform the Bay of Plenty Regional Spatial Plan (2014). Final Draft (Revised). Available at (online access $2017 \quad 01 \quad$ 19): https://www.boprc.govt.nz/media/373872/regional-council-agenda-28-august-2014-part2.pdf.

[25] Planning For Social Infrastructure And Community Services For Urban Growth Areas (2012). Online access (2017 $01 \quad 15)$ : http://www.elton.com.au/wordpress/wpcontent/uploads/2012/05/Implementation-Guide.pdf.

[26] Socialinès apsaugos ir darbo ministerija. Socialinis pranešimas - 2004, Vilnius: Puntukas, 2004.

[27] Social infrastructure planning (2007). Implementation Guideline No. 5. South East Queensland Regional Plan 2005-2026. Online access (2017 01 10): http://www.dilgp.qld.gov.au/resources/guideline/ImplementationGuideline5.pdf.

[28] Statistical yearbook of Lithuania 2015. (2016). Vilnius: Statistics Lithuania.

[29] Titcomb, L. A. (2000). Need Analysis. ICYF Evaluation Concept Sheet. Tucson: The University of Arizona. Available at (online access 201701 10): https://extension.arizona.edu/evaluation/sites/extension.arizona.edu.evaluation/files/docs/n eeds.pdf.

[30] Watanabe, Y. P (2007). Program evaluation: Utilizing needs analysis for decision making. TESOL Convetion. Available at (online access $2017 \quad 01 \quad 19$ ): http://www.nflrc.hawaii.edu/evaluation/files/TESOL2007_handout_YA.pdf. 